Article

\title{
Project-Based Learning and the Acquisition of Competencies and Knowledge Transfer in Higher Education
}

\author{
María del Carmen Granado-Alcón ${ }^{1}$, Diego Gómez-Baya ${ }^{1}$ (D) Eva Herrera-Gutiérrez ${ }^{2, *(\mathbb{D} \text {, }}$ \\ Mercedes Vélez-Toral ${ }^{1, *(D)}$, Pilar Alonso-Martín ${ }^{1}$ and María Teresa Martínez-Frutos ${ }^{2}$ \\ 1 Department of Social, Developmental and Educational Psychology, Faculty of Education, \\ Psychology and Sport Sciences, El Carmen Campus, University of Huelva, 21007 Huelva, Spain; \\ granado@dpsi.uhu.es (M.d.C.G.-A.); diego.gomez@dpee.uhu.es (D.G.-B.); pilar.alonso@dpsi.uhu.es (P.A.-M.) \\ Department of Developmental and Educational Psychology, Faculty of Psychology, Espinardo Campus, \\ University of Murcia, 30100 Murcia, Spain; mariateresa.martinez12@um.es \\ * Correspondence: evahg@um.es (E.H.-G.); maria.velez@dpee.uhu.es (M.V.-T.)
}

Received: 30 October 2020; Accepted: 27 November 2020; Published: 2 December 2020

\begin{abstract}
The aim of this paper is to contribute to the body of knowledge about project-based learning (PBL) methodology in higher education by describing and analysing interrelations between competencies, and their contribution to knowledge transfer (KT) and students' rating of the project. The sample consisted of 464 students from the Universities of Huelva $(\mathrm{N}=347 ; 74.8 \%)$ and Murcia $(\mathrm{N}=117 ; 25.2 \%)$, enrolled in the second year of a degree in either Infant or Primary Education. Data was collected through a self-administered questionnaire comprising a total of 53 items measuring general, specific, and transversal competencies, as well as students' rating of the project. Competencies were selected from the course programmes for the degrees in Infant and Primary Education. Preliminary results showed that competencies were moderately to highly acquired after PBL, and that students reported notable KT as well as a positive assessment of the project. KT showed a high degree of association with students' ratings and was established as a key factor in learning and learner satisfaction in higher education.
\end{abstract}

Keywords: project-based learning (PBL); higher education; competencies; knowledge transfer (KT); rating

\section{Introduction}

In today's globalized world, students and teachers face multiple unforeseeable challenges of increasing complexity and uncertainty, the solutions to which will require creativity and self-reliance beyond the safe inflexibility of established responses. As United Nations Educational, Scientific and Cultural Organization (UNESCO) [1] underlines, we need to create "sustainable citizens" capable of collaborating, speaking up, and acting for positive change. In this regard, Education for Sustainable Development (ESD) empowers people to change their way of thinking and to work towards the transformation of society, redirecting education and helping people to develop the knowledge, skills, values, and behaviours necessary for developing a sustainable future. Among other dimensions, ESD takes into account pedagogy, learning environments, and the psychological processes involved in the end result of learning. It conceives of teaching and learning as interactive and learner-centred, promoting practices that are exploratory, transformative, and oriented towards action. Nowadays, the orientation about how to promote sustainable citizenship is based on an outcome-based competence approach that could help to close the gap between knowledge and action [2]. 
Thus, it has been emphasized that instead of promoting certain behaviours and ways of thinking, it is about fostering an emancipatory concept of ESD focused, in particular, on building ability to think critically about-and beyond-what specialists say and to check sustainable development ideas [3,4].

In this regard, there is a general consensus that "sustainable citizens" need to have certain key (or transversal) competencies that allow them to engage constructively and responsibly with today's world. Examples of these key competencies are collaborative work, capacity for anticipation, strategic and critical thinking, integrated problem-solving, and capacity for self-awareness [5-7]. The methodology of project-based learning (PBL) is based on the premise that learning is a dynamic, interactive process, the final objective of which should be engagement with a real-world context. It is ideally suited to developing transversal competencies, and to enabling students to learn to adapt to the demands of an uncertain and changing environment and contribute to the fulfilment of the Sustainable Development Goals (SDGs), which are so important for ensuring our survival in the future.

This paper aims to contribute to our knowledge of PBL in higher education, as a methodology to enhance and develop those competencies that promote sustainable citizens, by describing and analysing the interrelations among competencies from two courses in the Degree in Education, "Psychological Foundations of Special Education" and "Diversity in Child Learning and Development", and the association of these with knowledge transfer (KT) and students' rating of the project.

\section{Literature Review}

One of the challenges currently facing higher education is the development of methodologies which empower learners to respond innovatively to the problems and challenges they face now and will face in the future. Specifically, the recommendations of the Conference of Chancellors of Spanish Universities (CRUE, in the Spanish acronym) [8] for the curriculum of students of the degree in Primary Education include professional Competencies to lead (in the nearest future) educational projects related to ESD — that is, to train proactive and participatory professionals that will be able to make responsible decisions based on a divergent analysis of the complex and changing reality.

PBL is featured among the methodological shifts in students' and teachers' roles promoted by the Organisation for Economic Co-operation and Development (OECD) [9]. Central to the approach is the idea that the teaching process must be based on students' reconstruction of experience. Educational psychologists note that one of the underlying principles of the methodology is the change in the roles traditionally assigned to teachers and students. Teachers are not just instructors but guides in the learning process [10], while for their part students are not just passive listeners but active learners whose actions and reflection form the foundation of solutions to problems [11]. This educational approach demands from teachers the use of instructional strategies collectively referred to as constructivist teaching methods $[12,13]$, and aims to promote in the students a positive attitude towards exploring and discovering knowledge and to develop aptitudes such as critical thinking and collaborative skills while working in groups [14,15]. Early advocates of this concept of learning and teaching, such as Kilpatrick, named it the "Project Teaching Method" [10]. This denomination is still used today but is frequently replaced by the term "project-based learning" or "PBL" [16], understood as encompassing two methods, problem-based learning and PBL, due to the many similarities between the two $[17,18]$.

Definitions of PBL identify it as a kind of collaborative work carried out by a group of people within the confines of an academic program $[19,20]$. Other significant aspects include the need for research, the importance of self-directed work, the use of various resources, the presentation of a final report, and, most importantly, the meaningful internalization of competencies while working [10,21-24]. PBL helps students to take responsibility of their own learning, particularly in their understanding and application of academic concepts. Furthermore, students manage authentic materials that integrate academic knowledge with real-world practices $[25,26]$. The methodology focuses on the process of students' learning through research and reflection directed at solving a problem set by the teacher, in which the students' actions are coordinated towards finding solutions and understanding and integrating 
concepts into a report, while working both alone and in a group [27-31]. Different authors have noted that the benefits of this methodology can be viewed from a general and a specific point of view [32,33].

From a general perspective, PBL allows the goals of the European Higher Education Area (EHEA) to be applied, promoting and integrating a dynamic learning approach in which skills, values, attitudes, and competencies for coping with real professional contexts are highly valued [34]. At a more specific level, the use of PBL methodology provides students with useful intellectual tools and improves their perception of learning. With respect to intellectual tools, these include developing effective learning strategies, such as problem-solving, planning, and learner autonomy while learning to research a topic [16,35], and cross-cutting skills transferable to new situations or other academic subject areas [36-38]. In terms of perception of learning, project-based approaches have been found to increase motivation, develop competencies and content knowledge [39,40], enhance students' perception of their learning progress [37,41], improve group work skills, promote positive attitudes towards investing effort and interest, and develop oral skills for presenting the results of their work [39]. In addition, the competencies gained are retained for longer [42], the activation of prior knowledge is facilitated, students' abilities for working autonomously and finding reliable sources of information are improved, and their critical reasoning develops, along with their social interaction and self-cognition skills [43,44].

The application of PBL to higher education has also had a significant impact on training courses $[29,45,46]$. In the last few decades, the approach has shown itself to be especially effective applied to degrees in Education [37,38,45,47-50], as well as Psychology [51], Sports Science [52], and Educational Psychology [53]. Among the positive outcomes associated with PBL methodology, teachers and students have reported high degrees of acquisition of competencies, increased motivation, an appreciation of constructive learning environments $[23,37,40,54]$, and a better perception of the learning process [41].

Additionally, PBL promotes the recognition of the interconnectivity between academic subjects for solving problems. It forces students to turn to knowledge acquired in different courses, to integrate this, and to go back to the initial problem with a more integral and dynamic view [55]. Interdisciplinary work through PBL helps to overcome students' difficulties perceiving academic subjects not as isolated content but interrelated. Morin [56] reports that students normally receive learning in an over-compartmentalised fashion, which can impede them from integrating knowledge when this is required to solve real-life problems [57]. It is clear that integration and transfer do not occur automatically, and in this respect PBL methodology is a significant tool for dealing with complex problems [58]. Various trials carried out in the fields of Education and Psychology have proved very efficient [48,59-63] and have provided the foundation for more recent research and innovation programs in higher education, which have not only evaluated the project in question alongside students' perception of their acquisition of competencies [37,51,57], but also examined students' perception of KT [49].

In line with previous literature, the aim of this paper is to contribute to the knowledge about the use of PBL in higher education to, among other things, achieve the objectives of ESD by describing and analysing interrelations among competencies, and the associations of these competencies with both KT and students' rating of the project. Kapetaniou and Lee [64] reported that universities' current role must transcend from their two main traditional missions of teaching and research and accomplish a third mission which relates to KT. In our educational context, KT implies the fact that students learn behaviours, develop skills, and acquire knowledge which is applied in other contexts as evidence of how behaviours can be repeated in a new situation [65]. One of the methodologies linked with $\mathrm{KT}$ is the PBL that focuses on the idea that teaching process must be based on student's experience construction, implying that teachers are just guides of the learning process [10] and that students are not just listeners but also explorers and knowledge discoverers whose aptitudes like thinking skill and critical thinking are developed while working in groups [14,15]. Some evidence shows that working through PBL at the university is possible [66], but recent research points out that in higher education KT continues to be disregarded and activities following this objective occur very sporadically [6]. 
However, there is some evidence reporting that when using this methodology, teachers and students perceive positive results in relation to competency acquisition; this possibility of promoting active and responsible learning in a guided and constructive environment is much more prone to develop students' intrinsic motivation [21,49]. To this end, the following objectives were addressed: (1) to provide an overall description of the perceived acquisition of competencies-generic, specific, and transversal-as well as students' rating of the project; (2) to analyse the relationship between students' degree of satisfaction regarding competency acquisition and their project rating and KT; and (3) to explain project rating in terms of perceived $\mathrm{KT}$ and competency acquisition.

\section{Methodology}

\subsection{Sample}

An exploratory and comparative cross-sectional study was developed based on data from a questionnaire. The sampling method used was the non-random and incidental sampling method. The context of the study was a Higher Education Teaching Innovation Project at the Universities of Huelva and Murcia (Spain) during the 2017-2018 academic year. A total of 387 students ( $85.2 \%$ women) in their second year of a degree in either Infant or Primary Education (54.3\% and 45.7\%, respectively) answered the questionnaire. Concerning age distribution, participants were aged $18-47$, with a mean age of $21.46(\mathrm{SD}=3.91)$. From the total, participation at the University of Huelva showed 270 students (69.9\%; age: M: 21.8; SD: 3.8) from Infant Education (24.4\%-boys: $1.29 \%$ vs. girls: $23.04 \%$ ) and Primary Education (45.6\%-boys: $12.94 \%$ vs. girls: $32.62 \%$ ). Participants at the University of Murcia studying Infant Education showed 116 students (30.1\%—boys: $0.51 \%$ vs. girls: $29.58 \%$; age: M: 20.6; SD: 4.7).

\subsection{Instrument}

Data were collected by means of a specially designed questionnaire entitled "Perception of the Acquisition of Academic Competencies through PBL", which consisted of a total of 58 items, as illustrated in Table 1 below. Empirical validation went through qualitative and quantitative analysis. Before the final data collection, we proceeded as follows. For qualitative analysis of reliability and validity, we checked the items from the questionnaire with 76 students in order to detect repetitions or unclear items. At the same time, we sent the questionnaire to six experts in our research field to evaluate its validity through Individual Aggregate Method This process of validation was individual and without contact among the experts. From their reports, the items that did not give information, were reiterative, or were written in a subjective way were deleted. For quantitative reliability and validity, we applied Exploratory Factorial Analysis using as extraction method principal components and as rotation method varimax. Data analysis showed Kaiser-Meyer-Olkin Test $(\mathrm{KMO})=0.850$ and significant Bartlett's sphericity coefficient showed $p=0.000$. Six factors were obtained explaining $61 \%$ of the total variance. Factors showed to confirm the two big blocks of the questionnaire. The six factors were individual general competencies (factor 1), grouped general competencies (factor 2), specific and transversal competencies (factor 3), methodological valuation of the project (factor 4), KT (factor 5), and organizational valuation of the project (factor 6). Additionally, it was calculated that Cronbach's Alpha $=0.932$.

Following a set of basic demographic questions (items 1-9), there were five sections: General Competencies (GC) (items 10-27), sub-divided into Group General Competencies (GGC), focusing on teamwork (items 10, 18-22, and 24-27), and Individual General Competencies (IGC), focusing on individual learning (items 11-17 and 23); Specific Competencies (SC) (items 28-35), designed to evaluate the perceived depth of study; Transversal Competencies (TC) (items $36-40$ and 50), measuring respondents' perception of having gained knowledge and/or skills transferable to other courses in their degree; respondent's evaluation of the project (items 41-49, 51-53, and 67); and knowledge transfer (KT) (items 54-66). Measurement of the variables varied. A five-point Likert scale (ranging from "1: Totally disagree" to "5: Totally agree") was used to analyse perceived competencies (items 10-53, 59-60, 62, 64, and 66), while a dichotomy scale was used for items $54-56$. Items $55,57,58,61,63$, and 65 were open 
and categorised posteriori according to the answers given. A ten-point scale (0-10) was used for item 67. There was also an open-ended section for respondents to write personalised evaluations of their experience of PBL. The competencies under analysis were drawn from the Curriculum Framework for the courses "Psychological Foundations of Special Education" and "Diversity in Child Learning and Development", both imparted in the second year of the degrees in Primary and Infant Education.

Table 1. Design of questionnaire "Perception of The Acquisition of Academic Competencies Through PBL".

\begin{tabular}{|c|c|c|c|c|}
\hline Section & & Items & Focus & Question Type \\
\hline Demographic data & & $1-9$ & $\mathrm{n} / \mathrm{a}$ & \\
\hline \multirow[t]{2}{*}{$\begin{array}{c}\text { General } \\
\text { Competencies (GC) }\end{array}$} & $\begin{array}{c}\text { Group General } \\
\text { Competencies (GGC) }\end{array}$ & $\begin{array}{c}10 \\
18-22 \\
24-27\end{array}$ & teamwork & Likert scale \\
\hline & $\begin{array}{l}\text { Individual General } \\
\text { Competencies (IGC) }\end{array}$ & $\begin{array}{c}11-17 \\
23\end{array}$ & individual learning & Likert scale \\
\hline $\begin{array}{c}\text { Specific } \\
\text { Competencies (SC) }\end{array}$ & & $28-35$ & depth of study & Likert scale \\
\hline $\begin{array}{c}\text { Transversal } \\
\text { Competencies (TC) }\end{array}$ & & $\begin{array}{c}36-40 \\
50\end{array}$ & transferrable skills & Likert scale \\
\hline Project Evaluation & & $\begin{array}{c}41-49 \\
51-53 \\
67\end{array}$ & & $\begin{array}{c}\text { Likert scale } \\
0-10 \text { scale (67) }\end{array}$ \\
\hline $\begin{array}{l}\text { Knowledge } \\
\text { Transfer (KT) }\end{array}$ & & $54-66$ & $\begin{array}{l}\text { sharing of } \\
\text { knowledge }\end{array}$ & $\begin{array}{c}\text { Likert scale }(59-60,62,64,66) \\
\text { dichotomy scale }(54,56) \\
\text { open question }(55,57,58,61,63,65)\end{array}$ \\
\hline
\end{tabular}

\subsection{Data Analysis Design}

The Kolmogorov-Smirnov test indicated that the study variables did not follow a normal distribution $(p<0.001)$. Thus, non-parametric statistics were calculated in order to analyse the data. First, descriptive statistics (i.e., mean and standard deviation) were calculated for each of the items and for the overall dimensions of competencies (i.e., general, specific, and transversal), project rating, and KT. Reliability of the measures was calculated by examining Cronbach's $\alpha$ and the Guttman split-half coefficient. As well, factorial validity was studied by performing exploratory factor analysis in each study variable. Second, bivariate zero-order Spearman correlations were calculated between competencies (i.e., general, specific, and transversal), KT, student rating, and overall rating. Third, two hierarchical regression analyses were performed in order to analyse the effects on the student and overall ratings of demographics, competencies, and KT. Collinearity tests were conducted (Durbin-Watson test), as well as bootstrap analyses to calculate confidence intervals for B scores. All the above analyses were carried out with the program SPSS 21.0. Fourth, a path analysis was conducted, based on the previous analyses, to examine the relationships between the variables. The overall model fit was examined by calculating robust indicators, such as Satorra-Bentler $\chi^{2}$, Comparative Fit Indec (CFI), and The Root Mean Square Error of Approximation (RMSEA). Standardised coefficients were reported regarding the effects included in the model. These analyses were performed using the statistical program EQS 6.3.

\section{Results}

4.1. Results of Objective 1: Overall Description of Perceived Acquisition of Competencies-Generic, Specific, and Transversal-and Project Rating

General Competencies (GC) were grouped into Group General Competencies (GGC), in which the students rated the learning achieved through interactions within their team (variables GGC2-7 and GGC13), and Individual General Competencies (IGC), in which each student rated the degree to which they had constructed their own learning (variables IGC1, IGCI8-12, and IGC14-17). See Table 2 for general results and Appendix A (Table A1) for specific results. The results showed that PBL methodology was positively rated by the students in terms of general competencies as a whole (GC: $\mathrm{M}=4.19 ; \mathrm{SD}=0.73$ ), and in both group (GGC: $\mathrm{M}=3.61 ; \mathrm{SD}=0.79$ ) and individual competencies (IGC: 
$\mathrm{M}=4.17 ; \mathrm{SD}=0.84)$. The majority of students expressed agreement with the idea that PBL methodology enabled them to achieve a range of competencies, in particular individual competencies, although the most frequent option with respect to group competencies was that of "neither agree nor disagree". The highest scores were for the items "PBL improved my analytical skills" $(\mathrm{M}=4.39$; $\mathrm{SD}=0.680)$ and "PBL made me understand the need to carry out research and/or intervention in the field of child diversity" $(\mathrm{M}=4.39 ; \mathrm{SD}=0.713)$, both of which pertained to IGC. Concerning reliability, this scale showed excellent internal consistency, as indicated by $\alpha=0.91$ and Guttman $=0.81$. Furthermore, good factorial validity was observed, $\mathrm{KMO}=0.91$, Bartlett's test of sphericity $\chi^{2}(136)=2906.14$, and $p<0.001$. A factor with an eigenvalue of 6.88 reached a percentage of $40.45 \%$.

Table 2. Students' rating of the PBL project: competency acquisition, KT, and Rating

\begin{tabular}{ccc}
\hline & Mean $(\boldsymbol{M})^{\mathbf{1}}$ & Standard Deviation (SD) \\
\hline General Competencies (GC)-overall & 4.19 & 0.732 \\
Group General Competencies (GGC) & 3.61 & 0.798 \\
Individual General Competencies (IGC) & 4.17 & 0.845 \\
Specific Competencies & 4.13 & 0.827 \\
Transversal Competencies (TC) & 3.75 & 1.054 \\
Knowledge Transfer (KT) & 3.72 & 0.928 \\
Overall Rating of PBL Project & 3.68 & 0.977 \\
Overall score for learning potential of PBL (0 to 10) & 8.05 & 0.995 \\
\hline
\end{tabular}

${ }^{1}$ Mean Range: $1-5$.

Specific Competencies (SC) explored students' perceptions of the degree to which PBL methodology enabled them to gain, at an individual level, an understanding of the theoretical concepts of the courses they were studying (see Table 2 for overall results and Appendix A (Table A2) for specific results). The overall results for specific competencies showed that students were in agreement that PBL methodology represented an effective way to acquire those competencies ( $\mathrm{SC}: \mathrm{M}=4.13$; $\mathrm{SD}=0.827$ ). The competencies which received the highest scores were those concerning normative/non-normative child development, learning processes, and intervention strategies (SC28: $\mathrm{M}=4.25 ; \mathrm{SD}=0.73$; $\mathrm{SC} 31$ : $\mathrm{M}=4.42 ; \mathrm{SD}=0.71 ; \mathrm{SC} 32: \mathrm{M}=4.19 ; \mathrm{SD}=0.82$, respectively). This scale showed good internal consistency reliability, as showed by $\alpha=0.85$ and Guttman $=0.64$. As well, exploratory factor analysis indicated a good factorial validity, $\mathrm{KMO}=0.80$, Bartlett's test of sphericity $\chi^{2}(28)=1410.21$, and $p<0.001$. A factor with an eigenvalue of 3.91 reached a percentage of $48.85 \%$.

The items focusing on Transversal Competencies (TC) were aimed at discovering the extent to which PBL methodology helped students to appreciate transversal skills (use of technology, learning in another language, collecting data, etc.) at the time of use in the project in which they were involved. See Table 2 for overall results and Appendix A (Table A3) for specific results. The overall results of students' perception of the potential of PBL methodology for generalizing skills learnt in the context of the course were unclear and showed a wide deviation, with "neither agree nor disagree" $(\mathrm{M}=3.75 ; \mathrm{SD}=1.054)$ being the most frequent option. The competency with the highest rating was the increased knowledge of data collection methodology through questionnaires, interviews, and observation (TC38: $\mathrm{M}=4.18 ; \mathrm{SD}=0.83$ ). Concerning reliability, this scale showed acceptable internal consistency, as indicated by $\alpha=0.69$ and Guttman $=0.66$. Furthermore, good factorial validity was found, $\mathrm{KMO}=0.75$, Bartlett's test of sphericity $\chi^{2}(15)=388.06$, and $p<0.001$. A factor with an eigenvalue of 2.49 showed an explained variance of $41.48 \%$.

With respect to perceived KT, most of the students $(80 \%)$ perceived the knowledge acquired through the PBL methodology as applicable to other courses comprising the Degree in Education. Fewer, but still more than half the students (59.6\%), considered that such contents could be applied to their daily life (see Table 3). This scale showed good internal consistency reliability, as showed by $\alpha=0.81$ and Guttman $=0.76$. Exploratory factor analysis indicated a good factorial validity, $\mathrm{KMO}=0.81$, Bartlett's test of sphericity $\chi^{2}(10)=607.43$, and $p<0.001$. A factor with an eigenvalue of 2.87 reached an explained variance of $57.32 \%$. 
Table 3. Students' perceived KT.

\begin{tabular}{|c|c|c|c|c|c|c|c|}
\hline & & $\%$ & University & $\%$ & $\mathrm{X}^{2}$ & $\mathbf{P}$ & Phi Effect Size $^{1}(\omega)$ \\
\hline \multirow{4}{*}{$\begin{array}{l}\text { Knowledge acquired in this course is } \\
\text { applicable to other courses in the degree. }\end{array}$} & \multirow{2}{*}{ Yes } & \multirow[b]{2}{*}{82} & Huelva & 81.4 & \multirow[t]{4}{*}{0.233} & \multirow[t]{4}{*}{0.629} & \multirow{8}{*}{-0.225} \\
\hline & & & Murcia & 83.5 & & & \\
\hline & \multirow{2}{*}{ No } & \multirow{2}{*}{18} & Huelva & 18.6 & & & \\
\hline & & & Murcia & 16.5 & & & \\
\hline \multirow{4}{*}{$\begin{array}{l}\text { Knowledge acquired in this course is } \\
\text { applicable to my daily life. }\end{array}$} & \multirow{2}{*}{ Yes } & \multirow{2}{*}{59.6} & Huelva & 52.4 & \multirow[t]{4}{*}{19.447} & \multirow[t]{4}{*}{0.000} & \\
\hline & & & Murcia & 76.5 & & & \\
\hline & \multirow{2}{*}{ No } & \multirow{2}{*}{40.4} & Huelva & 46.6 & & & \\
\hline & & & Murcia & 23.5 & & & \\
\hline
\end{tabular}

${ }^{1}$ Phi Values range from 0 , indicating a null effect size, to 1, indicating that the relationship between the variables is perfect.

The overall results of perceived KT showed that the majority of students selected "neither agree nor disagree" with respect to the potential for applying the knowledge they had acquired to other contexts $(\mathrm{M}=3.72$; $\mathrm{SD}=0.928)$. The most highly rated items for KT were "project-based learning helped me to make connections to knowledge in other subject areas in the Degree in Education" (TK2: $\mathrm{M}=3.92 ; \mathrm{SD}=0.909$ ) and "Project-based learning showed me how to cite papers following APA norms" (TK5: $\mathrm{M}=3.90 ; \mathrm{SD}=0.840$ ). In contrast, the least rated item was "Experience of the methodological principles involved in the 'Project for Methodological Development' (as applied to the subjects 'The Psychological Foundations of Special Education' and 'Diversity in Child Learning and Development') has been of use to me in other subjects" (KT1: $\mathrm{M}=3.45 ; \mathrm{SD}=1.039)$ (See Appendix A, Table A4).

In relation with students' rating of the PBL Project, overall results showed that the majority of students $(\mathrm{M}=3.68$; $\mathrm{SD}=0.977)$ selected "neither agree nor disagree" with respect to the PBL project (time investment, personal knowledge, classmates, materials, and learning opportunities). The most highly rated item was "PBL helped me in my academic training" (SV8: $\mathrm{M}=4.42 ; \mathrm{SD}=0.721$ ), while the least rated item was "The teaching staff devoted very little time to the course" (SV6: $M=1.82 ; \mathrm{SD}=1.147$ ). However, the latter cannot be considered a negative rating as it implicitly suggests that there was too little time available for teachers to deliver the project (See Appendix A, Table A5). This scale showed acceptable internal consistency reliability, as showed by $\alpha=0.64$ and Guttman $=0.48$. As well, exploratory factor analysis indicated a good factorial validity, $\mathrm{KMO}=0.77$, Bartlett's test of sphericity $\chi^{2}(66)=1477.40$, and $p<0.001$. A factor with an eigenvalue of 3.97 reached a percentage of $33.11 \%$.

\subsection{Results of Objective 2: To Analyse the Relationship between Students' Degree of Satisfaction Regarding Competency Acquisition and Their Project Rating and KT}

As can be seen in Table 4, moderate to high means were observed across the range of competencies, the highest being general competencies and the lowest being transversal. Notable scores were registered for both the project rating and overall student rating, with similar scores also being returned in respect of KT. Furthermore, good internal consistency reliability was detected for the general and specific competencies, as well as for KT, while an acceptable reliability for an instrument still in development was found for the transversal competencies and the project rating. The bivariate correlations showed positive and significant associations between all the variables. Hence, higher scores in the competencies (i.e., general, specific, and transversal) were found to be associated with higher scores in both KT and the rating scales (for both the overall learning potential of PBL and the project itself). Moreover, higher KT was also related to higher ratings. The three types of competencies were positively interrelated.

Table 4. Spearman bivariate correlations between variables.

\begin{tabular}{lcccccc}
\hline & $\mathbf{1}$ & $\mathbf{2}$ & $\mathbf{3}$ & $\mathbf{4}$ & $\mathbf{5}$ & $\mathbf{6}$ \\
\hline 1. General Competencies & 1 & & & & & \\
2. Specific Competencies & $0.62^{* * *}$ & 1 & & & & \\
3. Transversal Competencies & $0.52^{* * *}$ & $0.57^{* * *}$ & 1 & & & \\
4. Project Rating & $0.52^{* * *}$ & $0.35^{* * *}$ & $0.35^{* * *}$ & 1 & & \\
5. Overall Rating & $0.43^{* * *}$ & $0.30^{* * *}$ & $0.29^{* * *}$ & $0.50^{* * *}$ & 1 & \\
6. KT & $0.42^{* * *}$ & $0.40^{* * *}$ & $0.39^{* * *}$ & $0.43^{* * *}$ & $0.27^{* * *}$ & 1 \\
\hline \multicolumn{7}{l}{${ }^{* * *} p<0.001}$. \\
\end{tabular}




\subsection{Results of Objective 3: Explanation of Ratings in Terms of Perceived Acquisition of Competencies and KT}

Tables 5 and 6 present the results of two hierarchical regression analyses carried out separately to explain the scores for the overall and project rating scales on the basis of demographic data and the scores for the competencies and KT. In these regression analyses, no autocorrelation was detected in the sample, as indicated by Durbin-Watson test $=1.81$.

In step 1, demographics were found not to have any significant effect on overall rating or on the project rating scale. In step 2, general competencies showed a significant positive effect on both scales. However, the effect of the general competencies was greater on the project scale than on the overall scale, with a correspondingly higher explained variance ( $36 \%$ vs. $16 \%$, respectively). Finally, in step 3, KT was found to have a significant and positive effect only on the project rating scale, with an explained variance of $8 \%$. Following these results, the scores in the project scale were used for subsequent analysis.

A path analysis was tested in which: (a) general, specific, and transversal competencies were interrelated; (b) these competencies were found to have effects on KT; and (c) both KT and general competencies showed effects on project rating. The model showed good overall data fit (Satorra-Bentler $\left.\chi^{2}(2, \mathrm{~N}=387)=2.31, p=0.315, \mathrm{CFI}=0.998, \mathrm{RMSEA}=0.02\right)$. All standardised residuals were very low (between -0.1 and 0.1 ) and all measurement equations were significant. The three competencies (i.e., general, specific, and transversal) were positively interrelated, with a stronger association between the general and specific competencies. The general competencies presented a positive effect on KT. Moreover, both general competencies and KT showed positive effects on the project rating. The model gave an explained variance of $22 \%$ for KT and $36 \%$ for project rating. Figure 1 presents the standardised coefficients of the effects.

Table 5. Hierarchical regression analyses (I) to examine overall and project ratings according to demographics, competencies (i.e., general, specific, and transversal), and KT.

\begin{tabular}{|c|c|c|c|c|c|c|}
\hline \multirow[b]{2}{*}{ Step } & \multirow[b]{2}{*}{ Variable } & \multicolumn{4}{|c|}{ Overall Rating } & \multirow[t]{2}{*}{ B Confidence Interval } \\
\hline & & $\mathbf{F}$ & $R^{2}$ & $t$ & $\beta$ & \\
\hline \multirow[t]{9}{*}{1} & & 1.89 & 0.03 & & & \\
\hline & Gender & & & -1.92 & -0.15 & $-0.75,0.01$ \\
\hline & Age & & & -0.24 & -0.02 & $-0.06,0.05$ \\
\hline & Access to university & & & 1.22 & 0.11 & $-0.11,0.47$ \\
\hline & Degree course & & & -1.04 & -0.10 & $-0.70,0.22$ \\
\hline & Academic year & & & -1.71 & -0.12 & $-0.95,0.07$ \\
\hline & Session (a.m./p.m.) & & & 0.91 & 0.09 & $-0.10,0.27$ \\
\hline & Minor & & & -1.38 & -0.12 & $-0.22,0.04$ \\
\hline & Teacher & & & 0.46 & -0.05 & $-0.14,0.22$ \\
\hline \multirow[t]{12}{*}{2} & & $5.30 * * *$ & 0.19 & & & \\
\hline & Gender & & & -2.40 & $-0.18^{*}$ & $-0.79,-0.08$ \\
\hline & Age & & & -0.08 & -0.01 & $-0.05,0.05$ \\
\hline & Access to university & & & 1.22 & 0.11 & $-0.11,0.45$ \\
\hline & Degree & & & -1.46 & -0.14 & $-0.74,0.11$ \\
\hline & Academic year & & & -1.14 & -0.08 & $-0.74,0.20$ \\
\hline & Turn & & & 1.06 & 0.10 & $-0.08,0.26$ \\
\hline & Minor & & & -0.62 & -0.05 & $-0.16,0.08$ \\
\hline & Teacher & & & -0.15 & -0.01 & $-0.17,0.15$ \\
\hline & General Competencies & & & 2.75 & $0.33^{* *}$ & $0.16,0.99$ \\
\hline & Specific Competencies & & & 0.39 & 0.05 & $-0.32,0.48$ \\
\hline & Transversal Competencies & & & 0.61 & 0.06 & $-0.20,0.38$ \\
\hline \multirow[t]{13}{*}{3} & & $5.21 * * *$ & 0.20 & & & \\
\hline & Gender & & & -2.42 & $-0.18^{*}$ & $-0.78,-0.08$ \\
\hline & Age & & & -0.14 & -0.01 & $-0.05,0.05$ \\
\hline & Access to university & & & 1.23 & 0.11 & $-0.10,0.45$ \\
\hline & Degree & & & -1.41 & -0.13 & $-0.72,0.12$ \\
\hline & Academic year & & & -1.09 & -0.07 & $-0.72,0.21$ \\
\hline & Turn & & & 1.08 & 0.10 & $-0.08,0.26$ \\
\hline & Minor & & & -0.53 & -0.04 & $-0.15,0.09$ \\
\hline & Teacher & & & -0.30 & -0.03 & $-0.19,0.14$ \\
\hline & General Competencies & & & 2.35 & $0.28 *$ & $0.08,0.92$ \\
\hline & Specific Competencies & & & 0.27 & 0.03 & $-0.35,0.45$ \\
\hline & Transversal Competencies & & & 0.47 & 0.05 & $-0.22,0.36$ \\
\hline & $\mathrm{KT}^{\mathrm{I}}$ & & & 1.87 & 0.14 & $-0.01,0.40$ \\
\hline
\end{tabular}


Table 6. Hierarchical regression analyses (II) to examine project rating according to demographics, competencies (i.e., general, specific, and transversal), and KT.

\begin{tabular}{|c|c|c|c|c|c|c|}
\hline \multirow[b]{2}{*}{ Step } & \multirow[b]{2}{*}{ Variable } & \multicolumn{4}{|c|}{ Project Rating } & \multirow[t]{2}{*}{ B Confidence Interval } \\
\hline & & F & $\mathbf{R}^{2}$ & $t$ & $\beta$ & \\
\hline \multirow[t]{9}{*}{1} & & $2.34 *$ & 0.05 & & & \\
\hline & Gender & & & -0.77 & -0.06 & $-0.31,0.13$ \\
\hline & Age & & & -1.45 & -0.13 & $-0.05,0.01$ \\
\hline & Access to university & & & 0.60 & 0.05 & $-0.11,0.22$ \\
\hline & Degree course & & & -1.08 & -0.11 & $-0.41,0.11$ \\
\hline & Academic year & & & -0.18 & -0.01 & $-0.32,0.27$ \\
\hline & Session (a.m./p.m.) & & & 1.85 & 0.19 & $-0.01,0.20$ \\
\hline & Minor & & & -1.05 & -0.09 & $-0.11,0.03$ \\
\hline & Teacher & & & 1.27 & 0.13 & $-0.04,0.17$ \\
\hline \multirow[t]{12}{*}{2} & & $13.45^{* * *}$ & 0.41 & & & \\
\hline & Gender & & & -1.32 & -0.09 & $-0.29,0.06$ \\
\hline & Age & & & -1.16 & -0.08 & $-0.04,0.01$ \\
\hline & Access to university & & & 0.47 & 0.04 & $-0.10,0.17$ \\
\hline & Degree & & & -1.80 & -0.14 & $-0.40,0.02$ \\
\hline & Academic year & & & 1.14 & 0.07 & $-0.10,0.37$ \\
\hline & Turn & & & 2.37 & $0.20 *$ & $0.02,0.18$ \\
\hline & Minor & & & 0.21 & 0.01 & $-0.05,0.07$ \\
\hline & Teacher & & & 0.57 & 0.05 & $-0.06,0.10$ \\
\hline & General Competencies & & & 4.07 & $0.42^{* * *}$ & $0.22,0.63$ \\
\hline & Specific Competencies & & & 0.93 & 0.10 & $-0.11,0.29$ \\
\hline & Transversal Competencies & & & 1.59 & 0.14 & $-0.03,0.26$ \\
\hline \multirow[t]{13}{*}{3} & & $16.93^{* * *}$ & 0.49 & & & \\
\hline & Gender & & & -1.49 & -0.09 & $-0.29,0.04$ \\
\hline & Age & & & -1.52 & -0.10 & $-0.04,0.01$ \\
\hline & Access to university & & & 0.51 & 0.04 & $-0.09,0.16$ \\
\hline & Degree & & & -1.75 & -0.13 & $-0.37,0.02$ \\
\hline & Academic year & & & 1.31 & 0.07 & $-0.07,0.36$ \\
\hline & Turn & & & 2.60 & $0.20^{*}$ & $0.03,0.18$ \\
\hline & Minor & & & 0.46 & 0.03 & $-0.04,0.07$ \\
\hline & Teacher & & & 0.19 & 0.01 & $-0.07,0.08$ \\
\hline & General Competencies & & & 3.20 & $0.31 * *$ & $-0.12,0.24$ \\
\hline & Specific Competencies & & & 0.61 & 0.06 & $-0.13,0.24$ \\
\hline & Transversal Competencies & & & 1.31 & 0.10 & $-0.05,0.22$ \\
\hline & KT & & & 5.60 & $0.34^{* * *}$ & $0.17,0.36$ \\
\hline
\end{tabular}

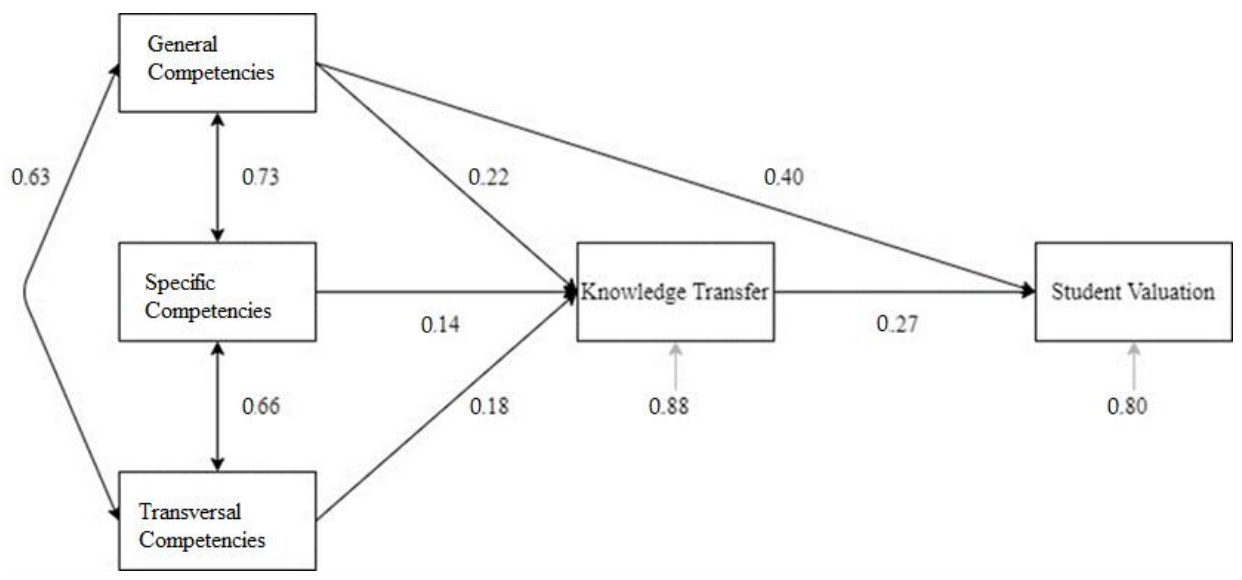

Figure 1. Path analysis of the relationships between competencies (i.e., general, specific, and transversal), $\mathrm{KT}$, and project rating.

\section{Discussion}

Education for a sustainable future challenges what is currently taught and how it is taught. Reorienting these aspects is crucial in this imminent transition in order to educate responsible global 
citizens. PBL is shown as a methodology with which students can acquire meaningful skills to achieve a professional training that is aligned with the objectives of ESD [1,67].

In terms of competencies, our results are supported by various researchers, who have demonstrated that working in groups gives students the opportunity to develop general competencies (GCs) by solving individual problems and developing their own knowledge construction through improving their ability to analyse, synthesize, and manage information [68] —in short, stimulating their capacity to learn, plan, and develop scientific thinking $[41,69]$.

With regard to specific competencies (SCs), what the students valued most was the opportunity the project offered to study learning differences among children with normative and non-normative development, and the need for carrying out research and devising interventions. In this respect, Meneses, Moraga, and Puchi [70] note that this methodology allows the student to start on the process of analysing specific cases, deducting principles and relationships, and formulating hypotheses. As such, the main advantage of the methodology is its favourability for encouraging the acquisition of learning related to research.

The results regarding the third set of competencies, transversal Competencies (TCs), showed that the item which rated most highly was the opportunity to learn how to use scientific tools capable of being applied to different subjects. We concur with multiple authors [71-77] that PBL methodology promotes the development of skill transfer, such as research abilities, autonomous learning, and critical thinking.

Finally, with regard to students' valuation of the project, our results were consistent with various studies in which teachers and students perceived the methodology as promoting active and responsible learning in a guided and constructive environment, especially apt for channelling students' intrinsic motivation [21,23,41,78], enhancing their perception of the learning process [41], and developing their ability to transfer knowledge to other learning contexts [79].

Regarding the second aim, positive associations were found between the research variables. Specifically, as found in previous studies, greater development of the three competencies (general, specific, and transversal) correlated with increased KT and higher student rating for the PBL program, while increased KT was also associated with higher student rating [37,49]. In addition, the competencies were positively interrelated.

Finally, with respect to the third aim, the multivariate analyses indicated that (a) general competencies and KT exerted positive direct effects on student rating of PBL and (b) the effects of the specific and transversal competencies on student rating were completely mediated by KT. The study thus provides evidence in favour of PBL as a methodological approach suitable for developing competencies and KT in higher education. In addition, PBL was highly rated by students, largely due to the degree of KT and the development of general competencies.

Therefore, and in terms of how students perceive acquisition of competencies and KT, our results let us deduce that working theoretical contents through PBL with Spanish university students is associated with high valuation of the methodology, positive learning satisfaction, and high possibilities of applying contents to different contexts from the initial one.

This notion is widely accepted by other researchers in the field (for example, [54,80-83]), who maintain that PBL methodology helps students to retain concepts, to recognise connections between different disciplines, and to apply the learning achieved to everyday situations. Further, it is a methodology that is highly compatible with one of the goals for teaching and learning proposed by the OECD for 2020 [9], which contemplates the modification of the roles of both students and teachers in the coming years, as also has been highlighted by the UN in its report for an ESD.

Despite these benefits, some limitations should be acknowledged and future lines of research suggested. First, because the study was cross-sectional, no causal relationships could be established, only associations between variables. A randomized controlled intervention, with pre- and post-assessment, would be desirable in order to test the efficacy of PBL in developing competencies and $\mathrm{KT}$, and for evaluating its rating compared to other methodologies. Second, the use of self-report measures may be biased by the subjective evaluation of respondents, so it would be beneficial to include 
objective measures aimed at improving the validity of the assessment of PBL. As well, more research is needed to examine psychometric properties of the scales. Third, because a convenience sample was used, the results cannot be generalized to undergraduate samples in other universities. In this case, future research should address a more appropriate gender distribution of the sample.

Fourth, more information is needed regarding the mechanisms involved in the relationships between the variables and the potential moderators. In this regard, a mixed-method design would provide qualitative data to complete the information collected through the use of self-reports.

These limitations aside, the results of the study do suggest some practical implications. These preliminary findings provide some evidence for the importance of PBL as a teaching methodology which promotes the development of competencies and KT in higher education. More research into educational innovation is needed to test the efficacy of this methodology for different degree subjects and academic years. In practical terms, student evaluation of the methodology was strongly favourable, and this undoubtedly had beneficial consequences for student motivation and engagement. An advantage of project-based methodology for university teachers is that it allows students to take control of their own learning. As Pedersen and Hobye [84] point out, the approach enables students to acquire significant learning and even to produce new knowledge. Young people are more reflective and more aware of their own learning in an active and collaborative context where new knowledge is exchanged and shared. This kind of collaborative and social learning methodology allows students to develop the feelings of group belonging, cohesion, and membership so important to create more responsible and engaged citizens who will develop sustainable social communities [3,4]. Indeed, the roles of the teacher and student are not traditional at all, and participants are challenged to translate theoretical course content into real-world applications, thus bringing the subject closer to professional practice. In short, our study suggests that PBL could be an innovative and potentially powerful methodology to improve learning in higher education, and its implementation will require a shift in the traditional distant roles of students and teachers. Further, this will allow the development of skills which will enable the construction of a more sustainable society.

Author Contributions: Conceptualization, M.d.C.G.-A., D.G.-B., E.H.-G., M.V.-T., P.A.-M., and M.T.M.-F.; methodology, M.d.C.G.-A., D.G.-B., E.H.-G., and M.V.-T.; validation, M.d.C.G.-A., D.G.-B., E.H.-G., M.V.-T., P.A.-M., and M.T.M.-F.; data curation, M.d.C.G.-A., D.G.-B., and P.A.-M.; writing-original draft preparation, M.d.C.G.-A., E.H.-G., and M.V.-T.; writing—review and editing, E.H.-G., M.V.-T., and M.T.M.-F. All authors have read and agreed to the published version of the manuscript.

Funding: This project has been financed by the Pro-Vice-Chancellor's Office for Innovation and Research at the University of Huelva.

Acknowledgments: The authors would like to express their gratitude to the students at the Universities of Huelva and Murcia (Spain) not only for their participation in the teaching project itself, but also for their time and consideration in completing the questionnaires.

Conflicts of Interest: The authors declare no conflict of interest. 


\section{Appendix A}

Table A1. Description of general competencies using PBL methodology.

\begin{tabular}{|c|c|c|c|c|c|c|c|}
\hline \multirow[b]{2}{*}{ GENERAL COMPETENCIES (GC)-PBL ... } & \multicolumn{3}{|c|}{ Total Sample } & \multicolumn{2}{|c|}{ University } & \multirow[b]{2}{*}{$\begin{array}{c}\text { Mean } \\
\text { Differences } \\
(M D)^{2}\end{array}$} & \multirow[b]{2}{*}{$d^{3}$} \\
\hline & $\mathbf{N}$ & $\begin{array}{l}\text { Mean } \\
(M)^{1}\end{array}$ & $\begin{array}{c}\text { Standard } \\
\text { Deviation } \\
(S D) \\
\end{array}$ & Huelva $(M ; S D)$ & Murcia $(M ; S D)$ & & \\
\hline GGC1 improved my problem-solving ability. & 386 & 4.02 & 0.658 & $4.06 ; 0.662$ & $3.95 ; 0.647$ & 0.108 & \\
\hline GGC2 helped me to work with others and to progress in my own learning. & 387 & 4.24 & 0.837 & $4.24 ; 0.880$ & $4.24 ; 0.730$ & -0.005 & N.S. \\
\hline GGC3 Working in groups allowed me to express doubts and improve my knowledge. & 387 & 4.27 & 0.738 & $4.27 ; 0.781$ & $4.28 ; 0.627$ & -0.010 & N.S. \\
\hline GGC4 Working in groups is beneficial for planning and organizing work. & 386 & 4.11 & 0.869 & $4.04 ; 0.924$ & $4.25 ; 0.709$ & -0.206 & Small \\
\hline GGC5 Working in group is beneficial for learning to make decisions. & 387 & 4.12 & 0.787 & $4.12 ; 0.785$ & $4.13 ; 0.797$ & -0.011 & N.S. \\
\hline GGC6 Working in groups is beneficial for learning to solve problems. & 386 & 4.23 & 0.769 & $4.19 ; 0792$ & $4.33 ; 0.707$ & -0.142 & N.S. \\
\hline GGC7 Working in groups in beneficial for learning to debate constructively. & 386 & 4.22 & 0.842 & $4.17 ; 0.864$ & $4.31 ; 0.785$ & -0.136 & N.S. \\
\hline IGC8 contributed to my self-learning. & 385 & 4.12 & 0.842 & $4.19 ; 0.851$ & $3.97 ; 0.805$ & 0.220 & Small \\
\hline IGC9 improved my analytical skills. & 386 & 4.39 & 0.680 & $4.43 ; 0.669$ & $4.29 ; 0.698$ & 0.140 & N.S. \\
\hline IGC10 improved my ability to synthesise information. & 386 & 4.34 & 0.677 & $4.33 ; 0.684$ & $4.35 ; 0.663$ & -0.020 & N.S. \\
\hline IGC11 increased my knowledge about how to access scientific documents. & 387 & 4.21 & 0.825 & $4.35 ; 0.765$ & $3.88 ; 0.866$ & 0.475 & Small \\
\hline IGC12 improved my ability to present a project with reasoned argumentation. & 387 & 4.18 & 0.742 & $4.17 ; 0.778$ & $4.21 ; 0.653$ & -0.041 & N.S. \\
\hline GGC13 let me interact positively with my team. & 387 & 4.32 & 0.744 & $4.28 ; 0.751$ & $4.41 ; 0.723$ & -0.137 & N.S. \\
\hline IGC14 made me understand the need to carry out research and/or intervention in the field of child diversity. & 387 & 4.39 & 0.713 & $4.36 ; 0.706$ & $4.46 ; 0.727$ & -0.095 & N.S. \\
\hline IGC15 improved my ability to speak in public. & 387 & 4.03 & 0.884 & $3.94 ; 0.890$ & $4.25 ; 0.833$ & -0.313 & Small \\
\hline IGC16 improved my ability to produce my own scientific texts. & 386 & 3.98 & 0.834 & $4.09 ; 0.766$ & $3.74 ; 0.934$ & 0.348 & Small \\
\hline IGC17 made me aware of another mode of learning. & 387 & 4.07 & 0.853 & $4.19 ; 0.820$ & $3.79 ; 0.870$ & 0.395 & Small \\
\hline OVERALL GENERIC COMPETENCIES SCORE & 387 & 4.19 & 0.732 & & & & \\
\hline OVERALL GENERIC INDIVIDUAL COMPETENCIES SCORE & 387 & 4.17 & 0.845 & & & & \\
\hline OVERALL GENERIC GROUP COMPETENCIES SCORE & 387 & 3.61 & 0.798 & & & & \\
\hline
\end{tabular}

${ }^{1}$ Mean range: $1-5 ;{ }^{2}$ Mean differences are significant at level $0.05 ;{ }^{3}$ Criterion for Cohen $d$ interpretation: non-significant N.S. $(<0.2)$; small $(\geq 0.2<0.5)$; medium $(\geq 0.5<0.8)$; big $(\geq 0.8-2)$. 
Table A2. Description of specific competencies using PBL methodology.

\begin{tabular}{|c|c|c|c|c|c|c|c|}
\hline \multirow[b]{2}{*}{ Specific Competencies-PBL } & \multicolumn{3}{|c|}{ Total Sample } & \multicolumn{2}{|c|}{ University } & \multirow[b]{2}{*}{$\begin{array}{c}\text { Mean } \\
\text { Differences } \\
(M D)^{2}\end{array}$} & \multirow[b]{2}{*}{$d^{3}$} \\
\hline & $\mathbf{N}$ & $\begin{array}{l}\text { Mean } \\
(M)^{1}\end{array}$ & $\begin{array}{c}\text { Standard } \\
\text { Deviation } \\
\text { (SD) }\end{array}$ & $\begin{array}{l}\text { Huelva } \\
(M ; S D)\end{array}$ & $\begin{array}{l}\text { Murcia } \\
(M ; S D)\end{array}$ & & \\
\hline SC28 deepened my understanding of normative child development. & 385 & 4.25 & 0.733 & $4.25 ; 0.745$ & $4.25 ; 0.709$ & 0.003 & N.S. \\
\hline SC29 deepened my understanding of non-normative child development. & 387 & 4.15 & 0.772 & $4.14 ; 0.803$ & $4.19 ; 0.698$ & -0.053 & N.S. \\
\hline SC30 deepened my understanding of the learning processes in children without learning problems. & 384 & 4.11 & 0.821 & $4.17 ; 0.784$ & $3.97 ; 0.899$ & 0.198 & N.S. \\
\hline SC31 deepened my understanding of the learning processes in children with learning problems. & 387 & 4.42 & 0.710 & $4.38 ; 0.739$ & $4.53 ; 0.625$ & -0.149 & N.S. \\
\hline SC32 helped me learn how to apply tests to detect and/or devise interventions for children with special needs. & 385 & 4.19 & 0.826 & $4.29 ; 0.774$ & $3.97 ; 0.903$ & 0.311 & Small \\
\hline SC33 developed my basic skills in designing appropriate tools for measuring. & 384 & 3.80 & 0.923 & $4 ; 0.885$ & $3.35 ; 0.849$ & 0.652 & Medium \\
\hline SC34 made me aware of the basic framework of a scientific research paper. & 387 & 4.16 & 0.889 & $4.47 ; 0.693$ & $3.42 ; 0.866$ & 1.050 & Big \\
\hline SC35 showed me how to design a research project. & 386 & 4.02 & 0.949 & $4.36 ; 0.731$ & $3.23 ; 0.940$ & 1.123 & Big \\
\hline OVERALL SPECIFIC COMPETENCIES SCORE & & 4.13 & 0.827 & $4.25 ; 0.682$ & $3.86 ; 0.615$ & 0.386 & \\
\hline
\end{tabular}

${ }^{1}$ Mean range: $1-5 ;{ }^{2}$ Mean differences are significant at level $0.05 ;{ }^{3}$ Criterion for Cohen $d$ interpretation: non-significant N.S. $(<0.2)$; small $(\geq 0.2<0.5)$; medium $(\geq 0.5<0.8)$; big $(\geq 0.8-2)$.

Table A3. Description of transversal competencies using PBL methodology.

\begin{tabular}{|c|c|c|c|c|c|c|c|}
\hline \multirow[b]{2}{*}{ Transversal Competencies-PBL } & \multicolumn{3}{|c|}{ Total Sample } & \multicolumn{2}{|c|}{ University } & \multirow[b]{2}{*}{$\begin{array}{c}\text { Mean } \\
\text { Differences } \\
(M D)^{2}\end{array}$} & \multirow[b]{2}{*}{$d^{3}$} \\
\hline & $\mathbf{N}$ & $\begin{array}{l}\text { Mean } \\
(M)^{1}\end{array}$ & $\begin{array}{l}\text { Standard } \\
\text { Deviation } \\
\text { (SD) }\end{array}$ & $\begin{array}{l}\text { Huelva } \\
(M ; S D)\end{array}$ & $\begin{array}{l}\text { Murcia } \\
(M ; S D)\end{array}$ & & \\
\hline TC36 developed my ability to use computer resources to work on-line with my group. & 386 & 3.92 & 0.992 & $3.93 ; 0.977$ & $3.91 ; 1.030$ & 0.028 & N.S. \\
\hline $\begin{array}{l}\text { TC37 developed my ability to use computer resources to work with data (Excel spreadsheets, statistics programs, } \\
\text { PowerPoint presentations). }\end{array}$ & 385 & 3.35 & 1.065 & $3.63 ; 0.967$ & $2.71 ; 1.004$ & 0.921 & Big \\
\hline TC38 increased my knowledge of data collection methodology (questionnaires, interviews, observations, etc.). & 387 & 4.18 & 0.830 & $4.19 ; 0.812$ & $4.16 ; 0.874$ & 0.028 & N.S. \\
\hline TC39 developed my second language (English) skills for conducting searches on the topic of my project. & 386 & 3.36 & 1.249 & $3.63 ; 1.094$ & $2.72 ; 1.361$ & 0.909 & Big \\
\hline TC40 helped me learn how to include references following APA norms. & 387 & 3.97 & 0.971 & $4.13 ; 0.853$ & $3.61 ; 1.125$ & 0.571 & Medium \\
\hline TC41 developed my ability to use virtual platforms (Google classroom, Moodle, etc.) to carry out the project. & 387 & 3.75 & 1.221 & $3.78 ; 1.266$ & $3.70 ; 1.113$ & 0.080 & N.S. \\
\hline OVERALL TRANSVERSAL COMPETENCIES SCORE & & 3.75 & 1.054 & $3.88 ; 0.998$ & $3.46 ; 1.084$ & & \\
\hline
\end{tabular}

${ }^{1}$ Mean range: $1-5 ;{ }^{2}$ Mean differences are significant at level $0.05 ;{ }^{3}$ Criterion for Cohen $d$ interpretation: non-significant N.S. $(<0.2)$; small $(\geq 0.2<0.5)$; medium $(\geq 0.5<0.8)$; big $(\geq 0.8-2)$. 
Table A4. Description of knowledge transfer using PBL methodology.

\begin{tabular}{|c|c|c|c|c|c|c|c|}
\hline \multirow[b]{2}{*}{ Knowledge Transfer } & \multicolumn{3}{|c|}{ Total Sample } & \multicolumn{2}{|c|}{ University } & \multirow[b]{2}{*}{$\begin{array}{c}\text { Mean } \\
\text { Differences } \\
(M D)^{2}\end{array}$} & \multirow[b]{2}{*}{$d^{3}$} \\
\hline & $\mathbf{N}$ & $\begin{array}{l}\text { Mean } \\
(M)^{1}\end{array}$ & $\begin{array}{l}\text { Standard } \\
\text { Deviation } \\
(S D)\end{array}$ & $\begin{array}{l}\text { Huelva } \\
(M ; S D)\end{array}$ & $\begin{array}{l}\text { Murcia } \\
(M ; S D)\end{array}$ & & \\
\hline $\begin{array}{l}\text { KT1 I have experience of the "Project for Methodological Development", as carried out in the subjects "The Psychological } \\
\text { Foundations of Special Education" and "Diversity in Child Learning and Development", from previous subjects. }\end{array}$ & 386 & 3.45 & 1.039 & $3.51 ; 1.085$ & $3.32 ; 0.913$ & 0.184 & N.S. \\
\hline KT2 Project-based learning helped me to make connections to knowledge in other subject areas in the Degree in Education. & 383 & 3.92 & 0.909 & $3.94 ; 0.888$ & $3.85 ; 0.956$ & 0.102 & N.S. \\
\hline KT3 The project carried out in this course enabled me to acquire competencies from other subjects. & 385 & 3.77 & 0.899 & $3.84 ; 0.788$ & $3.61 ; 1.106$ & 0.228 & Small \\
\hline KT4 Project-based learning enabled me to understand other subjects better. & 383 & 3.57 & 0.954 & $3.61 ; 0.884$ & $3.48 ; 1.099$ & 0.124 & N.S. \\
\hline KT5 Project-based learning showed me how to cite papers following APA norms. & 383 & 3.90 & 0.840 & $3.96 ; 0.940$ & $3.78 ; 0.087$ & 0.100 & N.S. \\
\hline Global Knowledge Transfer Competencies Score & & 3.72 & 0.928 & $3.77 ; 0.917$ & $3.43 ; 0.832$ & & \\
\hline
\end{tabular}

Global Knowledge Transfer Competencies Score

$\begin{array}{llll}3.72 & 0.928 & 3.77 ; 0.917 & 3.43 ; 0.832\end{array}$

${ }^{1}$ Mean range: $1-5 ;{ }^{2}$ Mean differences are significant at level $0.05 ;{ }^{3}$ Criterion for Cohen $d$ interpretation: non-significant N.S. $(<0.2)$; small $(\geq 0.2<0.5)$; medium $(\geq 0.5<0.8)$; big $(\geq 0.8-2)$.

Table A5. Students' rating of the PBL methodology project.

\begin{tabular}{|c|c|c|c|c|c|c|c|}
\hline \multirow[b]{2}{*}{ Students' Rating of The PBL Project } & \multirow[b]{2}{*}{$\mathbf{N}$} & \multicolumn{2}{|c|}{ Total Sample } & \multicolumn{2}{|c|}{ University } & \multirow[b]{2}{*}{$\begin{array}{c}\text { Mean } \\
\text { Differences } \\
(M D)^{2}\end{array}$} & \multirow[b]{2}{*}{$d^{3}$} \\
\hline & & $\begin{array}{l}\text { Mean } \\
(M)^{1}\end{array}$ & $\begin{array}{c}\text { Standard } \\
\text { Deviation } \\
\text { (SD) }\end{array}$ & $\begin{array}{l}\text { Huelva } \\
(M ; S D)\end{array}$ & $\begin{array}{l}\text { Murcia } \\
(M ; S D)\end{array}$ & & \\
\hline SR1 Enough time was dedicated to the project. & 384 & 3.87 & 1.023 & $3.81 ; 1.084$ & $4.01 ; 0.853$ & -0.195 & N.S. \\
\hline SR2 My knowledge of this subject helped me to carry out the project. & 385 & 3.86 & 0.931 & $3.80 ; 0.997$ & $4.02 ; 0.737$ & -0.217 & Small \\
\hline SR3. I think I need more prior knowledge to be able to work on a project. & 386 & 3.53 & 1.171 & $3.72 ; 1.196$ & $3.10 ; 0.990$ & 0.615 & Medium \\
\hline SR4 Small groups still have many participants. & 383 & 2.27 & 1.319 & $2.30 ; 1.438$ & $2.19 ; 0.981$ & 0.102 & N.S. \\
\hline SR5 The teacher spent enough time on the project. & 385 & 3.86 & 1.033 & $3.84 ; 1.077$ & $3.92 ; 0.925$ & -0.086 & N.S. \\
\hline SR6 The teaching staff devoted very little time to the course. & 384 & 1.82 & 1.147 & $1.71 ; 1.180$ & $2.06 ; 1.028$ & -0.351 & Small \\
\hline SR7 The materials used in the course were useful. & 382 & 3.87 & 0.950 & $3.79 ; 1.010$ & $4.04 ; 0.764$ & -0.252 & Small \\
\hline SR8 PBL helped me in my academic training. & 387 & 4.42 & 0.721 & $4.37 ; 0.768$ & $4.55 ; 0.580$ & -0.183 & N.S. \\
\hline SR9 PBL provided a good foundation of knowledge for my future professional life. & 385 & 4.37 & 0.790 & $4.29 ; 0.838$ & $4.57 ; 0.623$ & -0.280 & Small \\
\hline SR10 PBL allowed me to learn more than traditional methodologies. & 387 & 3.92 & 1.018 & $3.93 ; 1.071$ & $3.91 ; 0.884$ & 0.025 & N.S. \\
\hline SR11 PBL methodology deepened my knowledge of the theoretical foundations of the subject on which my project is based. & 386 & 4.19 & 0.814 & $4.14 ; 0.846$ & $4.30 ; 0.725$ & -0.161 & N.S. \\
\hline SR12 I enjoyed going deeper into the theoretical aspects of the subject. & 386 & 4.23 & 0.809 & $4.16 ; 0.818$ & $4.39 ; 0.766$ & -0.229 & N.S. \\
\hline Overall rating for the learning possibilities of PBL $(0$ to 10$)$ & 385 & 8.05 & 0.995 & & & & \\
\hline OVERALL RATING OF THE PBL PROJECT & & 3.68 & 0.977 & $3.65 ; 1.026$ & $3.755 ; 0.821$ & & \\
\hline
\end{tabular}

${ }^{1}$ Mean range: $1-5 ;{ }^{2}$ Mean differences are significant at level $0.05 ;{ }^{3}$ Criterion for Cohen $d$ interpretation: non-significant N.S. $(<0.2)$; small $(\geq 0.2<0.5)$; medium $(\geq 0.5<0.8)$; big $(\geq 0.8-2)$. 


\section{References}

1. UNESCO. Division for Inclusion, Peace and Sustainable Development, Education Sector. In Education for Sustainable Development Goals: Learning Objectives; UNESCO: Paris, France, 2017; Available online: https://unesdoc.unesco.org/ark:/48223/pf0000247444 (accessed on 15 September 2020).

2. Rieckmann, M. Learning to transform the world: Key competencies in Education for Sustainable Development. In Issues and Trends in Education for Sustainable Development; Leicht, A., Heiss, J., Byun, W.J., Eds.; UNESCO: Paris, France, 2018; pp. 39-60.

3. Vare, P.; Scott, W. Learning for a change: Exploring the relationship between education and sustainable development. J. Educ. Sustain. Dev. 2007, 1, 191-198. [CrossRef]

4. Wals, A.E.J. Beyond unreasonable doubt. In Education and Learning for Socio-Ecological Sustainability in the Anthropocene; Wageningen University: Wageningen, The Netherlands, 2015; Available online: https: //edepot.wur.nl/365312 (accessed on 28 October 2020).

5. De Haan, G. The development of ESD-related competencies in supportive institutional frameworks. Int. Rev. Educ. 2017, 56, 315-328. [CrossRef]

6. Rieckmann, M. Future-oriented higher education: Which key competencies should be fostered through university teaching and learning? Futures 2012, 44, 127-135. [CrossRef]

7. Wiek, A.; Withycombe, L.; Redman, C.L. Key competencies in sustainability: A reference framework for academic program development. Sustain. Sci. 2011, 6, 203-218. [CrossRef]

8. Saenz-Rico, B.; Benítez, L.; Neira, J.M.; Sobrino, M.R.; D’angelo, E. Perfiles profesionales de futuros maestros para el desarrollo sostenible desde un modelo formativo centrado en el diseño de ambientes de aprendizaje. Foro Educ. 2015, 13, 141-163. [CrossRef]

9. Martínez, M.L.; Torrego, J.C. Programas y medidas educativas en España para alcanzar objetivos europeos. REDIE 2014, 16, 119-134. Available online: http://redie.uabc.mx/vol16no2/contenido-mtnez-torrego.html (accessed on 4 October 2020).

10. Clark, A.M. Changing classroom practice to include the Project Approach. ECRP 2006, 8, 150-172.

11. Dewey, J. How We Think; Prometheus Books: Amherst, MA, USA, 1933.

12. Santrock, J.W. Psicología de la Educación, 4th ed.; McGraw-Hill: Madrid, Spain, 2011.

13. Vygotsky, L.S. Thought and Language; MIT Press: Cambridge, MA, USA, 1962.

14. Eby, J.W.; Herrell, A.L.; Jordan, M.L. Teaching in the Elementary School: A Reflective Action Approach, 5th ed.; Pearson: London, UK, 2009.

15. Holzman, L. Viygotsky at Work and Play; Routledge: Oxford, UK, 2009.

16. Katz, L.; Chard, S.C. The project approach: An overview. In Approaches to Early Childhood Education; Roopnarine, J.L., Johnson, J.E., Eds.; Merrill: Columbus, OH, USA, 2000; pp. 175-190.

17. English, M.C.; Kitsantas, A. Supporting student self-regulated learning in problem- and project- based learning. IJPBL 2013, 7, 128-150. [CrossRef]

18. Guerra, A.; Kolmos, A. Comparing problem based learning models: Suggestions for their implementation. In PBL across the Disciplines: Research into Best Practice; Davies, J., de Graaff, E., Kolmos, A., Eds.; Aalborg Universitetsforlag: Aalborg, Denmark, 2011; pp. 3-16.

19. Poell, F.; Van der Krogt, F.J. Project-based learning in organizations: Towards a methodology for learning in groups. JWL 2003, 15, 217-228. [CrossRef]

20. Larmer, J.; Mergendoller, J.; Boss, S. Setting the Standard for Project Based Learning: A Proven Approach to Rigorous Classroom Instruction; Association for Supervision and Curriculum Development: Alexandria, VA, USA, 2015.

21. García-Ruiz, R.; González, N.; Contreras, P. La formación en competencias en la universidad a través de proyectos de trabajo y herramientas 2.0. Análisis de una experiencia. RUSC 2014, 11, 61-75.

22. Jones, N.F.; Rasmussen, C.M.; Moffitt, M.C. Real-Life Problem Solving: A Collaborative Approach to Interdisciplinary Learning; American Psychological Association: Washington, DC, USA, 1997.

23. Torres, J.J. Construcción del conocimiento en educación superior a través del aprendizaje por proyectos. REOP 2010, 21, 137-142. [CrossRef]

24. Flores-Fuentes, G.; Juárez-Ruiz, E. Project-Based Learning for the Development of Mathematical Competencies in High School. REDIE 2017, 19, 71-91. 
25. Bernabeu, M.D.; Cónsul, M. El método ABP. In Historia de un Cambio. Un Currículum Integrado con el Aprendizaje Basado en Problemas; Cónsul, M.C., Ed.; Enciclopedia Catalana SAU: Barcelona, Spain, 2007; pp. 33-53.

26. Fernández, M.; García, J.N.; De Caso, A.; Fidalgo, R.; Arias, O. El aprendizaje basado en problemas: Revisión de estudios empíricos internacionales. Rev. Educ. 2006, 341, 397-418.

27. Blumenfeld, P.C.; Soloway, E.; Marx, R.W.; Krajcik, J.S.; Guzdial, M.; Palincsar, A. Motivating Project-Based Learning: Sustaining the doing, supporting the learning. Educ. Psychol. 1991, 26, 369-398.

28. Benito, A.; Cruz, A. Introducción. In Nuevas Claves Para la Docencia Universitaria en el Espacio Europeo de Educación Superior; Benito, A., Cruz, A.C., Eds.; Narcea: Madrid, Spain, 2005; pp. 11-20.

29. Fernández-Jiménez, C.; López-Justicia, M.D.; Fernández, M.; Polo, M.T. Aplicación del aprendizaje basado en problemas para la formación de alumnado de educación en la atención a la discapacidad. Profesorado 2014, 18, 335-352.

30. Brassler, M.; Dettmers, J. How to enhance interdisciplinary competence-Interdisciplinary problem-based learning versus interdisciplinary project-based learning. IJPB 2017, 11. [CrossRef]

31. Warr, M.; West, R. Bridging Academic Disciplines with Interdisciplinary Project-based Learning: Challenges and Opportunities. IJPBL 2020, 14, 1-23. [CrossRef]

32. Balemen, N.; Özer Keskin, M. The effectiveness of Project-Based Learning on science education: A meta-analysis search. IOJET. 2018, 5, pp. 849-865. Available online: http://iojet.org/index.php/IOJET/ article/view/452/297 (accessed on 7 September 2020).

33. Chang, N.; Wang, Z.; Hsu, S.H. A Comparison of the Learning Outcomes for a PBL-based Information Literacy Course in Three Different Innovative Teaching Environments. Libri 2020, 70, 213-225. [CrossRef]

34. Huber, G.L. Aprendizaje activo y metodologías educativas. Rev. Educ. 2008, No Extraordinario, 59-81.

35. Brown, A.L.; Campione, J.C. Psychological theory and the design of innovative learning environments: On procedures, principles, and systems. In Innovations in Learning: New Environments for Education; Glaser, R., Ed.; Erlbaum: Mahwah, NJ, USA, 1996; pp. 289-325.

36. Vázquez, R.M.; Ángulo, J.F. El currículum en acción: Las tareas de enseñar y aprender. El análisis del método. In Saberes e Incertidumbres Sobre el Currículum; Gimeno, J.C., Ed.; Morata: Madrid, Spain, 2010; pp. 333-354.

37. Granado-Alcón, M.C.; Alonso-Martín, P.; Vélez-Toral, M.; Gómez-Baya, D.; Herrera-Gutiérrez, E.; Martínez-Frutos, M.T. Project Based Learning in higher education: Student's perception of transforming traditional learning into an active and constructivist experience. In Proceedings of the ICERI2018 Conference, Seville, Spain, 12-14 November 2018; pp. 9510-9517.

38. Casals, E.; García, I.; Noguera, E.; Payá, M.; Tey, A. Innovación y mejora de la docencia universitaria mediante la metodología de Aprendizaje Basado en Problemas (ABP). RIE-OEI 2005, 36, 10-11.

39. Rodríguez-Sandoval, E.; Cortés-Rodríguez, M. Evaluación de la estrategia pedagógica “aprendizaje basado en proyectos": Percepción de los estudiantes. Avaliação 2010, 15, 143-158. [CrossRef]

40. Willard, K.; Duffrin, M.W. Utilizing project-based learning and competition to develop student skills and interest in producing quality food items. J. Food Sci. Educ. 2003, 2, 69-73. [CrossRef]

41. Rodríguez-Sandoval, E.; Vargas-Solano, E.M.; Luna-Cortés, J. Evaluación de la estrategia “aprendizaje basado en proyectos". Educ. Educ. 2010, 13, 13-25. [CrossRef]

42. Mioduser, D.; Betzer, N. The contribution of project-based learning to high achievers' acquisition of technological knowledge. IJTDE 2007, 18, 59-77. [CrossRef]

43. Trujillo, F. Enseñanza basada en proyectos: Una propuesta eficaz para el aprendizaje y el desarrollo de las competencias básicas. Eufonía 2012, 55, 7-15.

44. Restrepo, B. Aprendizaje basado en problemas: Una innovación didáctica para la enseñanza universitaria. Educ. Educ. 2005, 8, 9-19.

45. Arias-Gundín, O.; Fidalgo, R.; García, J.N. El desarrollo de las competencias transversales en Magisterio mediante el aprendizaje basado en problemas y el método de caso. RIE 2008, 26, 431-444.

46. Hernández, A.; Lacuesta, R. Aplicación del Aprendizaje Basado en Problemas (PBL) bajo un enfoque multidisciplinar: Una experiencia práctica. In Conocimiento, Innovación y Emprendedores. Camino al Futuro; Ayala, J.C., Grupo de Investigación FEDRA, Eds.; Universidad de La Rioja: Logroño, La Rioja, Spain, 2007; pp. 30-43.

47. Mérida, R. Una investigación sobre aprendizaje basado en problemas en el marco del prácticum de Magisterio. Investig. Esc. 2005, 57, 31-46. 
48. Lee, J.S.; Blackwell, S.; Drake, J.; Moran, K.A. Taking a Leap of Faith: Redefining Teaching and Learning in Higher Education through Project-Based Learning. Interdiscip. J. Probl. Based Learn. 2014, 8, 2. [CrossRef]

49. Vélez-Toral, M.; Granado-Alcón, M.C.; Gómez-Baya, D.; Herrera-Gutiérrez, E.; Alonso-Martín, P.; Martínez-Frutos, M.T. Analysis of students' valuation related to Knowledge Transfer (KT) after a Project Based Learning in higher education. In Proceedings of the ICERI2018 Conference, Seville, Spain, 12-14 November 2018; pp. 9559-9568.

50. Sluijsmans, D.; Moerkerke, G.; Van Merriënboer, J.; Dochy, F. Peer assessment in problem based learning. Stud. Educ. Eval. 2001, 27, 153-173. [CrossRef]

51. Gómez-Baya, D.; Granado-Alcón, M.C.; Benítez-Montagut, I.; Mendoza-Berjano, R. Competence development, student valuation and knowledge transference after cooperative project-based learning. In Proceedings of the ICERI2019 Conference, Seville, Spain, 11-13 November 2019; pp. 3527-3530.

52. Gómez-Baya, D.; Granado-Alcón, M.C.; Morales-Fernández, E.; Trechera-Herreros, J.L. Empirical validation of cooperative project-based learning. In Proceedings of the ICERI2019 Conference, Seville, Spain, 11-13 November 2019; pp. 3535-3538.

53. García, J.N. El aprendizaje basado en problemas: Ilustración de un modelo de aplicaciones en Psicopedagogía. Cult. Educ. 2002, 14, 65-79. [CrossRef]

54. Prieto-Navarro, L. Aprendizaje activo en el aula universitaria: El caso del aprendizaje basado en problemas. MiCo 2006, 64, 173-196.

55. Medina Nicolalde, M.; Tapia Calvopiña, M. El aprendizaje basado en problemas una estrategia para el trabajo interdisciplinario en el aula. Olimpia 2017, 14, 142-153.

56. Morin, E. La Mente bien Ordenada; Seix Barral: Barcelona, Spain, 2001.

57. Blanco, M.; Corchuelo, B.; Corrales, N.; López, M. Ventajas de la interdisciplinariedad en el aprendizaje. Experiencias innovadoras en la Educación Superior. In XI Jornadas Internacionales de Innovación Universitaria. Educar para Transformar; Universidad Europea: Madrid, Spain, 2014; pp. 11-20. Available online: https: //abacus.universidadeuropea.es/bitstream/handle/11268/3564/x_jiiu_2014_11.pdf?sequence=2 (accessed on 23 May 2020).

58. Rodríguez-Santero, J.; Torres-Gordillo, J.J.; Perea-Rodríguez, V.H. Aportaciones del método ABP en la consecución de competencias de acción profesional. Bordón 2016, 68, 155-177. [CrossRef]

59. Alonso, A. A proposal for future Primary School Teachers. Collaborative environment designing strategies from children's Visual Culture. Arte Individuo Soc. 2011, 23, 121-134.

60. Arias-Gundín, O.; Fidalgo, R.; Robledo, P.; Álvarez, L. Análisis de la efectividad del aprendizaje basado en problemas en el desarrollo de competencias. In Actas do X Congresso Internacional Galego-Português de Psicopedagogía; Universidade do Minho: Braga, Portugal, 2009; pp. 2666-2678. Available online: http: //www.educacion.udc.es/grupos/gipdae/documentos/congreso/Xcongreso/pdfs/t7/t7c195.pdf (accessed on 14 April 2020).

61. Egido, I.; Aranda, R.; Cerrillo, R.; De La Herrán, A.; De Miguel, S.; Gómez, M.; Hernández, R.; Izuzquiza, D.; Murillo, F.J.; Pérez, M. Aprendizaje basado en problemas (ABP). Estrategia metodológica y organizativa del currículum para la calidad de la enseñanza en los estudios de Magisterio. RIFP 2006, 20, 137-149.

62. Márquez, C.V.; Uribe, J.I.; Montes, R.; Monroy, C.E.; Ruiz, E.D. Satisfacción académica con el ABP en estudiantes de licenciatura de la Universidad de Colima, México. Rev. Intercon. Psicol. Educ. 2011, 13, $29-44$. Available online: http://www.redalyc.org/articulo.oa?id=80218382003 (accessed on 25 October 2020).

63. Fernández, E. El discurso de la formación basada en competencias profesionales. Un análisis crítico de la formación inicial de profesionales en la Educación Superior. REIFOP 2009, 12, 151-160.

64. Kapetaniou, C.; Lee, S.H. A framework for assessing the performance of universities: The case of Cyprus. Technol. Forecast. Soc. Chang. 2017, 123, 169-180. [CrossRef]

65. Detterman, D.K.; Sternberg, R.J. Transfer on Trial: Intelligence, Cognition, and Instruction; Ablex Publishing: Westport, CT, USA, 1993.

66. De Miguel, M. Modalidades de Enseñanza Centradas en el Desarrollo de Competencias. Orientaciones para Promover el Cambio Metodológico en el Espacio Europeo de Educación Superior; Ediciones Universidad de Oviedo: Oviedo, Spain, 2006; Available online: https:/www2.ulpgc.es/hege/almacen/download/42/42376/modalidades_ ensenanza_competencias_mario_miguel2_documento.pdf (accessed on 19 June 2020).

67. Santoveña-Casal, S.; Fernández Pérez, M.D. Sustainable Distance Education: Comparison of Digital Pedagogical Models. Sustainability 2020, 12, 9067. [CrossRef] 
68. Saavedra, M.C. Aprendizaje Cooperativo basado en la Investigación en la Educación Superior. REDU 2018, 16, 235-250. [CrossRef]

69. Martínez, F.; Herrero, L.C.; González, J.M.; Domínguez, J.A. Project Based Learning Experience in Industrial Electronics and Industrial Applications Design; Universidad de Valladolid: Valladolid, Spain, 2007; Available online: http://www.greidi.infor.uva.es/articulos/EUPProjectBased.pdf (accessed on 12 September 2020).

70. Meneses, P.; Moraga, A.; Puchi, R. Diagnóstico de estrategias de aprendizaje para la orientación y focalización de los apoyos académicos que favorecen la permanencia de estudiantes de primer año en la Universidad de La Frontera. In Congreso CLABES VI. Sexta Conferencia Latinoamericana Sobre el Abandono en la Educación Superior; Escuela Politécnica Nacional: Quito, Ecuador, 2016; Available online: http://revistas.utp.ac.pa/index. php/clabes/article/view/1339 (accessed on 2 September 2020).

71. Garrigós, J.; Valero-García, M. Hablando sobre aprendizaje basado en proyectos con Júlia. REDU 2012, 10, 125-151. [CrossRef]

72. Biggs, J. Calidad del Aprendizaje Universitario; Narcea: Madrid, Spain, 2005.

73. Boud, D.; Feletti, G.I. The Challenge of Problem-Based Learning, 2nd ed.; Kogan Page: London, UK, 1997.

74. Duch, B.J.; Groh, S.E.; Allen, D.E. The Power of Problem-Based Learning. A Practical "How to" for Teaching Undergraduate Courses in any Discipline; Stylus Publishing: Sterling, VA, USA, 2001.

75. Hmelo-Silver, C.E. Problem-Based Learning: What and How Do Students Learn? Educ. Psychol. Rev. 2004, 16, 235-266. [CrossRef]

76. Toledo, P.; Sánchez, J.M. Aprendizaje Basado en Proyectos: Una experiencia universitaria. Profesorado 2018, $22,471-491$.

77. Wilkerson, L.; Gijselaers, W.H. Concluding comments. New Dir. Teach. Learn. 1996, 68, 101-104.

78. Lam, S.; Cheng, R.W.; Ma, W.Y.K. Teacher and student intrinsic motivation in project-based learning. Instr. Sci. 2009, 37, 565-578. [CrossRef]

79. Mitchel, S.; Foulger, T.; Wetzel, K.; Rathkey, C. The negotiated project approach: Project-based learning without leaving the standards behind. Early Child. Educ. J. 2009, 36, 339-346. [CrossRef]

80. Maldonado, M. Aprendizaje basado en proyectos colaborativos. Una experiencia en educación superior. Laurus 2008, 14, 158-180.

81. Rojas Betancur, H.M. La importancia de las políticas públicas de formación en investigación de niños, niñas y jóvenes en Colombia, para el desarrollo social. Rev. Latinoam. Cienc. Soc. Niñez Juv. 2008, 6, 885-906.

82. Stentoft, D. Three Challenges for New Students Facing Problem-Based and Interdisciplinary Learning. In Interdisciplinarity and Problem-Based Learning in Higher Education: Research and Perspectives from Aalborg University; Jensen, A.A., Stentoft, D., Ravn, O., Eds.; Springer Publishing Company: New York, NY, USA, 2019; pp. 49-60.

83. Navarro, I.; González, C.; Botella, P. Aprendizaje basado en proyectos: Diferencias percibidas en la adquisición de competencias por alumnado universitario. Rev. Psicol. Educ. 2015, 10, 55-76.

84. Pedersen, S.; Hobye, M. Implications of Assessing Student-Driven Projects: A Case Study of Possible Challenges and an Argument for Reflexivity. Educ. Sci. 2020, 10, p. 19. [CrossRef]

Publisher's Note: MDPI stays neutral with regard to jurisdictional claims in published maps and institutional affiliations.

(C) 2020 by the authors. Licensee MDPI, Basel, Switzerland. This article is an open access article distributed under the terms and conditions of the Creative Commons Attribution (CC BY) license (http://creativecommons.org/licenses/by/4.0/). 